\title{
Structural Equation Modeling of Cognitive Determinants of Technology Integration Literacy in Ghanaian Higher Education
}

*Gideon Mensah Anapey: Instructional Technologist \& Counselling Psychologist, University of Education, Winneba, Ghana.

Dominic Kwaku Danso Mensah: Professor of Educational Management and Administration, University of Education, Winneba, Ghana.

Stephen Antwi-Danso: Senior Lecturer, Department of Psychology and Education, University of Education, Winneba, Ghana.

\begin{abstract}
Technological innovations are altering the lives of the poor, rich, nation's economics, and education globally. Hence, Ghana's commitment to formulate the ICT for Accelerated Development (ICT4AD) Policy in 2003 to achieve the transformative vision of competing favorably in the knowledge economy in addition to the introduction of ICT- related subjects in the Ghanaian schools to develop the human resources for indigenous knowledge development is laudable. However, instructional technologists feared that the Ghanaian ICT curriculum from basic to tertiary level might be too generic and lacking curriculum-specific integration literacy, thereby likely to widen the digital divide. To support Ghana's vision for ICT integration into higher education lessons, the current study sought to predict university graduates ' integration literacy from cognitive constructs using partial least squares structural equation modeling (PLSSEM) approach. The measurements and structural model fit indices were tested with SmartPLS Version 3. The results showed that students"goal-setting and need for achievement significantly predicted over $15 \%(R 2=.155)$ of ICT integrate skills. However, self-efficacy was not an important predictor $(t=1.74, p>.05)$ for students ICT integration literacy in the Ghanaian setting. We concluded that whilst graduates'goal-setting and need for achievement traits motivate them to acquire technology skills in the Ghanaian public universities, certainly, $85 \%$ of latent variables such as pedagogy, lecturers " computer integration competencies, and access remain unaccounted for per our structural model. The study recommends that career counsellors could design cognitive interventions to improve students' self-efficacy traits and educational administrators should encourage formative assessment by ICT instructors in their schools to enhance skills developments.
\end{abstract}

Key words: Structural equation modelling, Technology integration literacy in higher education, Counselling intervention.

International Journal of Educational Studies Vol. 1, No. 3, pp. 181-194

2018

OI: $10.53935 / 2641-533 \times v 13.87$

Corresponding Author: Gideon Mensah Anapey Funding: This study received no specific financial support.

Article History:

Received: 14 June 2018

Revised: 2 November 2018

Accepted: 29 November 2018

Published: 24 December 2018

(2) 2018 by the authors: licensee Academic

Publishing Group

| 181

\section{Introduction}

The current study attempts to explore cognitive factors likely to influence students ${ }^{6}$ ability to integrate technology into higher educational curriculum. Various arguments for technology applications into commerce, education, medicine, entrepreneurship, and industry are advanced. Therefore, our paper sought to examine which cognitive theories underpinned students ${ }^{6}$ technology integration into higher education curriculum in Ghanaian public universities. 


\section{Technological Influence on Higher Education Reforms}

Technological innovations are considered as disruptions that are influencing healthcare, education, pharmaceuticals, and market indices (Chiles, Tuggle, McMullen, Bierman, \& Greening, 2010) at the same time, singular solution that can provide jobs on large scale for teaming unemployed youths (Ács, Szerb, \& Autio, 2015). In a cautionary tone, some have suggested that realising the Schumpeterian's model of entrepreneurship, which hinges on innovation would be a delusion without technological entrepreneurship (Francoise \& Janviere, 2016). Nevertheless, under what circumstances do entrepreneurship strive? In the views of Hansemark (1997) conditions of sky rocketing unemployment rates might motivate individuals to commence their own enterprises -as a means of subsistencel within the context of larger social and business indicators. Therefore, the role of information and communication technology altering job processes has been discussed in the management literature (Laudon \& Laudon, 2007). Such innovations in the technology front have found expression in curriculum reforms in different countries including Ghana. For instance, in an executive summary to the 2007 Education Commission Report, Ghanaian public universities are mandated to re-examine their programmes in view of advances in knowledge and changing demands in the economy to produce highly competent human resources capable to spearhead industry and commerce (Ghana's Education Reform Report, 2007).

Likewise, the International Society for Technology Education (ISTE) is a leading non-profit organisation that promotes technology to support instructional delivery in both pre-university and university levels in the USA in collaboration with the National Council for Accreditation for Teacher Education (NCATE) over decades (Shelly, Cashman, Gunter, \& Gunter, 2006). Another body managed by the ISTE is the National Educational Technology Standards for Students (NETS-s). The standard for students seeks to evaluate students' technology integration literacy on six broad categories. These include (i) basic operations and concepts; (ii) social, ethical, and human issues; (iii) technology productivity tools; (iv) technology communications tools, (v) technology research tools; and (vi) technology problem-solving and decision-making applications. Educationists are increasingly advocating for standard-based learning and assessment that empowers learners to function in their specialised fields of study as well as their geographical settings (McMillan, 2007). Whilst fanatics such as Popham (2005) is vociferous on the ideals of standard-based education as most likely to empower students' learning much better than curriculum-based learning across states, McMillan further submits that different educational leaderships play key roles in setting the boundaries of what students should know and which competency frameworks are required after graduation. New technologies obviously result in job redesigns, human resource development, and continuous learning by employees to ensure returns on investment (Phillips \& Whalen, 2000). In the wake of technological innovations workplaces are witnessing, educational reforms are recommending ICTs in preparing students for the knowledge economy (National ICT for Accelerated Development Policy, 2003). Likewise, an investment in ICTs by educational institutions has been reported in the (This Is An Annual Review Document By The Ministry of Education). The report indicates that a remarkably $87 \%$ of second cycle schools in Ghana have computer laboratories with $97.4 \%$ reported having ICT teachers. Indeed, the 2010 report is a great case for examining technology access in Ghanaian schools. However, studies have shown a mismatch between access and integration literacy in Ghanaian universities with low technology competences reported (Yidana, 2007). Though Ghanaian education has no such standard-based education policy, the 2007 Education Commission Report chaired by Jophus Anamuah-Mensah urgently recommends universities to integrate ICTs into instructional delivery. The Review Committees' recommendations came at the heels of the ICT for Accelerated Development Policy (ICT4AD), which also identifies the need to incorporate ICTs into educational delivery in Ghanaian schools for accelerated national development (The Republic of Ghana, 2003). As part of the 2003 Policy's mission, it submits:

... to transform the educational system to provide the requisite educational, and training services and environment capable of producing the right type of skills and human resources required for developing and driving Ghana's information and knowledge-based economy and society, the Government is committed to a comprehensive programme of rapid deployment, utilisation and exploitation of 
ICTs within the educational system from primary school upwards (ICT4AD Policy, p.37).

Contextually, the ICT4AD Policy's admonition merges with the 2007 Education Reform, which has stated the embers of Ghana's education philosophy in the knowledge economy. The philosophy amongst other things states that the underlying theme for Ghana's education should be the training of well balanced (intellectually, spiritually, emotionally, and physically) scholars with requisite skills, knowledge, abilities, values, aptitudes for self-fulfilment and the socio-economic and political transformation of Ghana. Conversely, global economic challenges and weak economic indices of Ghana's employment market give cause for concern (Aryeetey \& Baah-Boateng, 2007). Ghana's graduates leaving school are expected to develop the requisite entrepreneurial competences to make significant contributions to organisations and nation building efforts with the potentials for ICTs in the information society. Views have it that Ghanaian graduates are rather criticised by employers as lacking working experience and knowledge for today's knowledge society.

Reflecting on the future of international careers of a growing technical and professional workers in his book, Inkson (2007) drew attention of practitioners seeking to assist cosmopolitan careerists to be more knowledgeable of, pay attention to the location-specific, contextual factors (political, economic, cultural, and technological) and lifestyles likely to impact millennial' careers. More challenge to career scholars is the revelation that many empirical studies in recent times report samples still opting for traditional career path (Cabrera, 2009; Sargent \& Domberger, 2007). In spite of Sullivan and Baruch (2009) believe that individuals ${ }^{6}$ desires are driving their entrepreneurial career choices rather than modification of traditional organisational structures, Inkson's admonition could have implications for career guidance and counselling professionals in the knowledge society and the need to predict youths ${ }^{6}$ career decision-making using sophisticated analytical tools with ecological validity. The need to orient graduates to appreciate the realities of weaning traditional careers and begin to focus on non-traditional career orientation could be relevant for economic growth and managing graduate employment in the Ghanaian context.

Whilst the extant literature highlights the positives of new careers in the $21^{\text {st }}$ century (Currie, Tempest, \& Starkey, 2006; Vardi \& Kim, 2007) little is known about the implications for individuals personality traits on new career directions with high demands for technology skills (Eby, Butts, \& Lockwood, 2003). Eby et al. also report that individuals who are open to new experiences, proactive, flexible, and aware of their strengths and weaknesses seem to be effective managers in today's workplace than those who do not. Alfred Marshall, a $19^{\text {th }}$ century economists began to realize the importance of knowledge and recommended, -Knowledge is our most powerful engine of production, with firms as facilitators of the growth (Cader, 2008). The competences of students leaving universities today require more than reading literacy as the CEO Forum on Education and Technology (2001: 1) summarises it in a publication titled, Key Building Blocks for Student Achievement in the $21^{\text {st }}$ Century the definition of students' achievement must be broadened to include $21^{\text {st }}$ century skills that students will require to thrive in the future. The world in which our students live is significantly different from that of yesterday. Thus, $21^{\text {st }}$ century skills should be considered within the context of rigorous academic standards. They are bridges to students' authentic, intellectually challenging works with ICT tools. Embodiment of technology literacy, innovative thinking, creativity, collaboration skills, economic and social literacy, high productivity, and effective communication skills are desired skills employers are seeking. Based on a review of the entrepreneurial career choice literature emphasising graduates ${ }^{6} 21^{\text {st }}$ century skills, it is legitimate to ask, are they equipped with $21^{\text {st }}$ century skills for critical thinking, digital innovativeness, team spirit, information literacy, technological proficiency, and strategic thinking, coupled with the right psychological dispositions to take make significant contributions to personal and societal development in the future? We are in the digital age with emerging twists to traditional entrepreneurship. Today's learners employ handheld devices, instant messaging, and smart phones to connect to friends, family, and subject matter experts and communities around the world. Active participation in the information-rich economy requires diverse ICT skills of Internet, social media, and digital creations (Shelly et al., 2006). Business processes are being digitised with enterprise solution systems on increasing basis (Pratt \& Adamski, 2005). Therefore, our students will require extraordinary entrepreneurial competences to innovate, and reengineer businesses for wealth creation.

International Journal of
Vol. 1, No. 3, pp. 181-194 2018

DOI: 10.53935/2641-533x.v1i3.87

Corresponding Author: Gideon Mensah Anapey Funding: This study received no specific Article History:

Received: 14 June 2018

Revised: 2 November 2018

Accepted: 29 November 2018

(1) 2018 by the authors; licensee Academic

Publishing Group

| 183 
Perhaps, these innovative minds reside in the young graduates from today's universities and colleges. University students' technology integration literacy would be greatly required to make significant contributions to the business activities in the information society.

By extension, career experts have the urgency to develop prospective and existing workers ' core competences such as creativity, emotional intelligence, digital literacy, knowledge, and abilities for successful career and job transitions (Lee, 2000; Reich, 1996). On such backdrop that the current study sought to examine the social-cognitive traits and technological competency of Ghanaian graduates. Higher educational institutions have strategic roles in developing $21^{\text {st }}$ century skills and digital knowledge for job creation.

\section{Theoretical Framework}

The social-cognitive frameworks of Albert Bandura (Self-Efficacy), Rotter (Locus of Control), McClelland (Need for Achievement), and Locke and Latham (Goal-Setting), set the tone for the study. Social-cognitivism is an umbrella term in the field of psychology with a scientific study of episteme situated within the social milieus one finds him/herself (Reisberg, 2010). Scott (2006) historically submits that studying individual actions without situating it within the powerful cultural systems could be dangerous for behavioural scientists. Scott also emphasised the evolutionary nature of cultural systems from society and national levels with multiple subjectivities that could be studied in unique ways based on a classical arguments of Wilhelm Dilthey (1883-1910) that the social sciences often revolve around the desire to _understand' cultural wholes to follow their fields' evolutions. Hobbis and Sutton (2005) postulate that cognitive frameworks are characterised by individuals' ability to process incoming information using core beliefs, assumptions, and automatic switching with psychological complexities. Consequently, the current study adopts five such cognitive models to investigate students preparedness to acquire technology integration literacy required of today's knowledge society.

\subsection{Self-Efficacy Theory}

Dominant amongst cognitive-based theories is Albert Bandura's self-efficacy theory, which often receives extensive application in entrepreneurship research (Sánchez, Carballo, \& Gutiérrez, 2011) and other life skills acquisitions. Grounded in social-cognitive theory, the dominant feature of self-efficacy has led others to suggest that it is one of the most researched topics in the fields of education and psychology (Celik, 2015) and preferably, the most popular form of expectancy belief in the applied psychology writings (Vancouver, More, \& Yoder, 2008). Bandura (1989) recent definition of selfefficacy highlights individuals' beliefs in their capabilities to execute -certain level of performance or desired outcomesll that influence situations and affect their lives. Similarly, Chen, Greene, and Crick (1998) added that entrepreneurship self-efficacy construct accounts for individuals' self-belief in their ability to engage in roles and execute entrepreneurial activities diligently. Earlier, Bandura (1989) also explains how positive or negative self-efficacy beliefs generally enhance or undermine individuals ${ }^{6}$ performance and motivation to undertake a challenge. Recently, Bandura (2004) acknowledges how social persuasion contributes to self-efficacy theory formulation. Invariably, in any given context, people's beliefs affect their choices, actions, efforts, resilience in the event of obstacles, how much stress and anxiety they will experiencell (Mackenzie \& Peragine, 2003).

Understanding sources of students' self-efficacy beliefs could be profound in the school environment as well. Ayres (2005) finds out that students with high self-efficacy beliefs regarding their ability to acquire new skills before they commence leadership development training are more likely to transfer learning to the workplace after completion of training. Others also report that peers (Bicego, 2006; Hoy $\&$ Spero, 2005) and faculty feedback (Lord, 2010) are crucial in that regard. Nevertheless, majority of the empirical researches on sources of self-efficacy have been targeted at high school and college-aged students in predominantly Westernised environment (Usher, 2009).

Contextual and demographic variables have also been found to influence self-efficacy development. Thus, gender, ethnicity, and learning domains (Britner \& Pajares, 2006; Lent, Brown, Gover, \& Nijjer, 1996; Pajares, Johnson, \& Usher, 2007) cited as important influences on self-efficacy. Incidentally, Kelly, Ali, Brush, and Corbett (2012) report differences in gender and entrepreneurship with men more likely to assume risk and recognise opportunities than their female counterparts. In a similar regard,

International Journal of 2018 Funding: This study received no specific Anancial support.

Received: 14 June 2018

Revised: 2 November 2018

Accepted: 29 November 2018

(C) 2018 by the authors: licensee Academic

Publishing Group

| 184 
others revealed that self-efficacy beliefs are relevant predictors of a person's attempt with a business behaviour such as launching a new enterprise and perseverance at a task when faced with challenges (Austin \& Nauta, 2016) and individuals' career choices (Lent, Brown, \& Hackett, 1994). Usher (2009) also reports in her article that Bandura's findings support - mastery experience as the most influential sourcell of efficacy beliefs. High levels of self-efficacy are associated with individuals ' belief that they possess the skills or qualities to successfully manoeuvre certain situations (Wise, 2007). Empirical evidence also suggests that relationships exist between social networks and efficacious beliefs with individual's access to information and peer support (Daly, Moolenaar, Bolivar, \& Burke, 2010). Consequently, understanding how students develop general self-efficacy could be of immense help to career counsellors with technology interest. Therefore, the overarching goal of this study is to explore business students' ${ }^{6}$ general task self-efficacy in relation to their technology integration literacy. Students beliefs in their capabilities to accomplish tasks from the locus of general task self-efficacy was measure in this study.

\subsection{Need for Achievement Model}

The Need for Achievement (nAch) theory is defined as fundamental motives directing individuals to mobilize internal and external resources in order to face challenges for personal, success, and excellence on tasks (Atkinson, 1958; McClelland, 1961). Using multivariate technique in a later work, Elizur (1986) discovers two dominant themes that explain the nAch construct. These are resource type (either internal or external) and time perspective relative to task performance (before, during, or after performance). Sagie (2002) further provides practical applications of Elizur's two facets of internal or external resources as when a person confronts a challenge in life. However, internal resources represent an individual's inner energy or orientation that involves efforts, responsibility, and avoidance or tolerance of favourable and unfavourable events instead of accepting easy responsibilities in life. Invariably, Sagie also says that external resources are -instrumental meansl that might include answers, approaches, and estimations in those situations requiring problem solving, decision-making, or risk calculations. From the definitions of the founding fathers (Atkinson \& McClelland) and Elizur's examples, the dominant theme underlying the nAch construct stems from an individual's ability to exercise his/her mental traits in decision-making regarding life's successes.

In the applications of the nAch theory, Matthews and Dagher (2007) confidently suggest that intentions of achieving goals are crucial variables for success. The bottom line is that the nAch factor is success-driven with the combination of one' $s^{6}$ inner core and careful applications of environmental resources for personal growth. Similarity, significant relationships exist between nAch and entrepreneurship construct across several studies (Johnson, 1990; Venkatapathy, 1984). Hence, the current study sought to examine the relevance of nAch to predicting Ghanaian students ' desire to learn ICT skills.

\subsection{Economic Locus Theory}

In the views of developmental psychologists, several human attitudes and behaviours are learnable through parental teachings and observations from significant other family members ${ }^{6}$ socialisation at infant stages; refers to as environmental determinism (Shaffer \& Kipp, 2007). Originally, the locus of control (LOC) theory has been attributed to Rotter in a classic monograph; where he states that personalities who belief that they can control events affecting them possess LOC (Rotter, 1966). Following the first seminar work by Rotter from his grounded theory that propounded the locus of control theory, over 600 publications on the construct continue to generate various conceptualisations (Kormanik \& Rocco, 2009) rather than achieving parsimonious definition. Others continue to express their worries about the inconsistencies in LOC results from scientific studies to-date (Lachman, 1986) with many more researchers advocating for domain-specific LOC scales instead of general concept definitions (Lefcourt, 1991; Spector, 1982). Rotter (1966) later suggested domain-specific measures of the LOC factor on the basis that the general applications of its scales tend to produce weak predictions with theoretical generalizability (Fournier \& Jeanrie, 1999). Millar and Shevlin (2007) provide enough evidence of increasing number of scientific studies using Rotter's internal-external locus of control scale. On the categories of LOC, Fournier and Jeanrie identified seven areas (decision-making, self-knowledge,

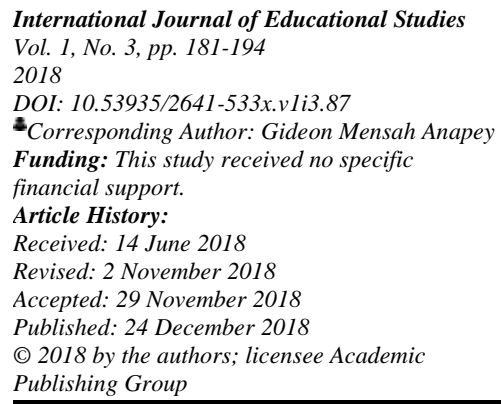

| 185 


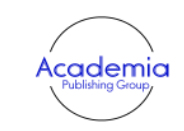

International Journal of Educational Studies Vol. 1, No. 3, pp. 181-194

2018

DOI: 10.53935/2641-533x.v1i3.87

* Corresponding Author: Gideon Mensah Anapey Funding: This study received no specific financial support.

Article History:

Received: 14 June 2018

Revised: 2 November 2018

Accepted: 29 November 2018

Published: 24 December 2018

(C) 2018 by the authors; licensee Academic

Publishing Group meaning of work, career planning, social and work environment, educational institutions, and job market) of career choices relating to LOC measure on specific domains. Testing such assumption in the Ghanaian context with graduating business students from Ghanaian public universities could also provide some form of cultural and ecological validation to Rotter (1966) LOC scale.

Similarly, Rotter (1966) locus of control theory is premised on a larger framework of a socialcognitive thinking (Senler, 2016). The views of the social-cognitive thinkers include individuals` ability to make informed decisions in relations to the cultural and social environments. Therefore, students ' use of the LOC theory in technology skills acquisition could have implications for cultural values and other social contexts Ghanaian students operate. According to Kormanik and Rocco (2009) the LOC construct has wide applications in human sciences and clinical trials.

The LOC construct has been applied to the study of diverse behaviours and attitudes in youth transition from school-to-work attitude and cognitive processes (Perry, Liu, \& Griffin, 2011). Such prediction of work ethics are based on Super, Savickas, and Super (1996) assumption that the youth are likely to be autonomous and self-motivated in mastering the tasks of crystallizing, specifying, and implementing their career choices whilst leaving school. Interestingly, Perry et al. reported that geographical dichotomy scores for urban and rural youths exist, which they sharply attributed to their cognitive views on future orientation in the world of work because of external factors such as labour market segregation, lack of financial resources, and discrimination. However, the researchers did not also rule out demographic variables such as age, race, social strata, gender, or combinations. Indeed, Lloyd and Hastings (2009) reported that age is a significant predictor of individuals ${ }^{6}$ locus of control. Lloyd and Hastings' conclude that development of locus of control is also a function of history of reinforcement and behavioural expectations.

In support of developmental process of internal and external locus of control, others conceive that one's social values and self-identification of self-knowledge play important roles as well (Ryan \& Connell, 1989). Such findings support (Rotter, 1966) description of human behaviour as contingent on social perceptions and outcomes individuals expect from their actions. Consequently, the current study positions the LOC construct within environmental factors (school, curriculum, family, and socialisation) as determinants of choices students could make in technology decision-making from Ghanaian public universities.

\subsection{Goal-Setting Theory}

Literature on goal-setting recognises the multiple constructs to describe individual's targeted behaviour (Pintrich, 2000). However, Pintrich points out that apart from achievement goals, individuals may be striving for several other goals in life as well. Generally, goals span many aspects of human life, which led (Ford, 1992) to classify 24 basic motivations including safety, belongingness, creativity, joy, mastery, exploration, understanding, and superiority, just to mention few. Thus, goals are - ubiquitous part of human life and one goal or the other drives every individual's task accomplishments (Collins, Mowbray, \& Bybee, 1999).

Goal is defined as the object or an objective an individual is striving to accomplish (Locke, Shaw, Saari, \& Latham, 1981). Contributing to its importance, Ontario Leadership Strategy Bulletin (2010) explains, -Goals help us focus our energy and actions, measure our progress, and ultimately achieve purposeful results.l Succinctly put, goals are desirable mental and physical states towards which people direct their actions and efforts (Rollinson, Broadfield, \& Edwards, 1998). Meacham (2004) offers that goals represent anticipated events that motivate individuals' behaviour. Clarifying multiple purposes of goals, Locke et al. state that they help individuals to achieve key performance indicators, guide action, help efforts on task, serve as encouragement, and support the development of strategic behaviour too. For the individual, empirical findings showed that goal-setting enables people to focus on finishing an overarching task (Marsh, Hicks, \& Bink, 1998; Marsh, Hicks, \& Bryan, 1999) as well as help people to suppress their destructive behaviours (Diefendorff, Snyder, \& Lord, 1997).

Goal-setting is a constituent of motivational models. Goals have intrinsic and extrinsic motivational attributes that influence the manner in which individuals" competence is evaluated (Elliot \& Harackiewicz, 1994). Hence, others consider goals as guides to everyday pursuits of humankind whether short-term, medium-term, or long-term (Kruglanski, 1996). Locke and Latham (1990) postulate that 


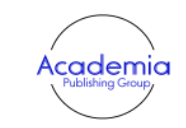

International Journal of Educational Studies Vol. 1, No. 3, pp. 181-194

2018

DOI: 10.53935/2641-533x.v1i3.87

"Corresponding Author: Gideon Mensah Anapey Funding: This study received no specific financial support.

Article History:

Received: 14 June 2018

Revised: 2 November 2018

Accepted: 29 November 2018

Published: 24 December 2018

(C) 2018 by the authors: licensee Academic

Publishing Group

| 187 difficult and realistic goals are likely to result in higher performances than unchallenging goals. GómezMiñambres (2012) also extended Locke and Latham (1990) original propositions on the effectiveness of goal-setting as well. Mediator elements of goals such as focus on selective tasks and the exclusion of activities in one's life has been identified with control over cognitive and physical effort proportionate towards goal attainment, as well as persistence through time until the goal is achieved (Simons \& Chabris, 1999). Other moderators include feedback, commitment, resource constraints, satisfaction, and efficaciousness of goals (Smith \& Hitt, 2005). Hence, the current study sought to explore cognitive traits in grit- goals considering mediators and moderators as covariates likely to influence Ghanaian business students' ability to set goals for their lives after school.

Developmental psychologists describe young adulthood as characterised by consideration of different options for identity and directions in later life (Arnett, 2000). Hill, Jackson, Roberts, Lapsley, and Brandenberger (2011) contend that establishing goals is one way to establish a - niche or role in lifell for the young adult. Incidentally, as graduates leave school, they are faced with myriad choices as to what careers they would be pursuing in the information age (World Bank, 2013) and high rates of unemployment (African Economic Outlook, 2015; Aryeetey \& Baah-Boateng, 2007; Munive, 2008). This is not to say that the future is bleak for today's youth but guiding them to negotiated job creations involving cognitive capabilities could provide them with some levels of assurances. Reliability of verbal self-reports generated with interviews, surveys, think-aloud, and simulated recall methods are of concerns to researchers (Pintrich, 2000). For instance, Wright (1992) laments the inability of literature to address the problem of construct validity of goal difficulty. Whilst the veracity of self-reports have not generated different approaches, Pintrich is quick to mention that the nature of goal constructs in themselves are cognitive in nature, hence, individuals have to recall such mental traits into consciousness. He then calls for researchers to construct valid test items to measure goals and apply standard psychometric testing to goal measures considering error variance including social desirability effects, maturation, and general contextual influences that may bias the self-reports from cases. Locke and Latham (1990) also noted that goal impediments are due to environmental factors such as change in policy, technology, and information. By extension, since goals are deemed personally constructed targets with environmental determinism, there could be variations in intra-reliability scores.

\section{Purpose of the Study}

Therefore, we sought to determine which cognitive factors would be significant determinants of students ${ }^{6}$ technology integration literacy from Ghanaian public universities. The essence of our findings would influence curriculum design in higher education in the area of technology deployment in teaching and learning. Similarly, career guidance and counselling psychologists could support Ghana's economic growth agenda by supporting graduates to develop their cognitive traits (self-efficacy, goal-setting, need for achievement, \& locus of control) towards the technology skill development using structural equation modelling (SEM) methodology. Hence, the subsequent section of this article outlines the SEM methods for the study.

\section{Research Hypotheses}

Based on the research goal, we formulated a SEM model that sought to answer these two main null hypotheses:

$\mathbf{H}_{\mathbf{0}}$ 1: students' cognitive traits will not significantly predict students' technology integration literacy in higher education,

$\mathbf{H}_{\mathbf{0}}$ 2: there will not be statistical relationships between cognitive traits in this study.

\section{Methodology \\ 6.1. Research Design}

The current study employed reflective model in partial least squares structural equation modeling (PLS-SEM) methodology. PLS-SEM is described as variance-based, second generation multivariate analysis technique that enables researchers to combine several variables for predictive effects on an outcome factor (Hair, Sarstedt, Ringle, \& Mena, 2012). PLS-SEM also uses dyadic approach of combining multiple linear regression and correlations between latent variables in data management, 
making it a powerful multivariate statistical tool today (Ringle, Silva, \& Bido, 2014). Garson (2016) (2016) explains that PLS methodology allows us to relate multiple independent variables to the se to outcome variables, rendering it use appealing to social scientists who are interested in examining multiple constructs' effects in a single study. We considered PLS-SEM as a research design for the current study based on the objective of testing how students develop five important traits for the knowledge society. Thus, we proposed to test the collective effects of goal-setting, need for achievement, and self-efficacy factors on technology integration literacy in higher education. In similar vein, the study sought to test individual effects of the five factors for counselling and educational administration policy designs.

\subsection{Participants and Sampling Approach}

We administered a factor analysed questionnaires to 709 university students with an average age of $24(\mathrm{M}=24.9 ; \mathrm{SD} \pm 4.01)$ from three government-funded Ghanaian universities. In this study, 38\% ( $\mathrm{n}=$ 226) females and $62 \%(n=443)$ males indicated their age with $6 \%(n=41)$ unable to state their sex. The samples constituted business students from five programmes (accounting, marketing, human resource, health administration, and general management). Specifically, 62\% $(\mathrm{n}=441)$ participants represented accounting; 14\% $(\mathrm{n}=102)$ human resource management, and 4\% ( $=29)$ marketing students. In addition, the ratio of male to female lack of computer and Internet access either at home or at school was 3:1 in this study. Thus, every three students without a computer, one was likely to be a female.

The three participating universities and the samples were selected using simple random sampling technique, which involves the use of a computer application to select a numbered sampling frame from a list of possible units (Babbie, 2010). Therefore a list of seven public universities offering business programmes were used based on two- year enrolment estimates (2015 to 2016) from the National Council for Tertiary Education (2016). A widely held believe that large sample size is not a requirement for PLS-SEM (Chin \& Newsted, 1999; Cool, Dierickx, \& Jemison, 1989) guided our choice of sample size. Chin and Newsted based their recommendation of small sample sizes on the power of PLS-SEM to reach accurate estimations based on summated scales and residuals analysis. Recently, Reinartz, Haenlein, and Henseler (2009) also support the argument for higher statistical power and lower mean estimation errors when used small sample sizes. Therefore, we are confident that our reflective PLSSEM would significantly predict the estimated structural model for the study.

\subsection{Instrumentation and Data Collection}

The study used a questionnaire that measured students ' cognitive and technology integration in education traits after factor analysis. Factor analysis enables researchers to eliminate weaker questionnaire items measuring a construct with strong coefficients (Field, 2009). Hence, the initial 30 items constructed based on the International Society for Technology in Education (ISTE) standards for students (NETS-S) were reduced to 11 based on 0.7 alpha values. The NETS-S comprised six standards for measuring students' technology competency. The standard was developed in the USA and was considered relevant for curriculum-specific ICTs integration in education globally. Subsequently, we measured students' cognitive traits based on self-efficacy (13-items), locus of control (32-items), need for achievement (6-items), and goal-setting (9-items) theories. Participants indicated their level of agreement or disagreements on a 5-point Likert scale ranging from _strongly agree ${ }^{6}$ (5) to _strongly disagree' (1).

Validity and reliability checks were ensured for the current study using SEM model fit statistics in the next section of this paper. However, the final questionnaires were administered to final year students from the three universities yielding great composite reliability and Cronbach's alpha values (see Table 1) - model fit statistics. To ensure ecological validity, the instruments were administered to participants in classrooms, whilst colleague lectures from ICT, Educational Administration and Management, and Guidance and Counselling departments provided face and construct validations. Averagely, each student used between 10 and 15 minutes to complete the instruments in the presence of the researchers. Averagely, $71.64 \%(n=236)$ return rate for the three universities was achieved.

International Journal of Edut. 1, No. 3, pp. 181-194
Vol. 2018

DOI: $10.53935 / 2641-533 x . v 1 i 3.87$

Corresponding Author: Gideon Mensah Anapey Funding: This study received no specific Article History:

Article History:
Received: 14 June 2018

Revised: 2 November 2018

Accepted: 29 November 2018

Published. 24 December 2018

(C) 2018 by the authors; licensee Academic

Publishing Group

| 188 


\section{Data Analyses and Discussion}

This section illustrates the data processing techniques based on partial least structural equation modeling (PLS-SEM). The model fit statistics, discriminant and convergent validity, cross-validity tests, and path confidents are reported for the study.

\subsection{Model Fit Statistics: Reflective Model for the Measurement Model}

Using bootstrapping technique in PLS-SEM, the t-tests of significance for the reflective and inner models were computed for our data based on Garson (2016) criterion of 1.96. Figure 1 shows the measurement and path models analysis with t-statistics. Remarkable results were produced with the selfefficacy trait as an exogenous variable to ICT integration literacy; though the least path score $(\mathrm{t}=1.97, \mathrm{p}$ $<.05)$. The reflective model showed that all indicator variables were statistically significant at .05 alpha level. By extension, we are confident in our measurement model to predict the structural model for the study. Similarly, the t-statistics recorded for the inner model were all significant $(\mathrm{P}<.05)$ since no constructed was less than 1.96 criterion, though the least $t$-value seen in the Figure 1 was between general task self-efficacy $(\mathrm{t}=1.974)$. Hence, we proceeded to examine the discriminant and convergent validities for the PLS-SEM model for our study.

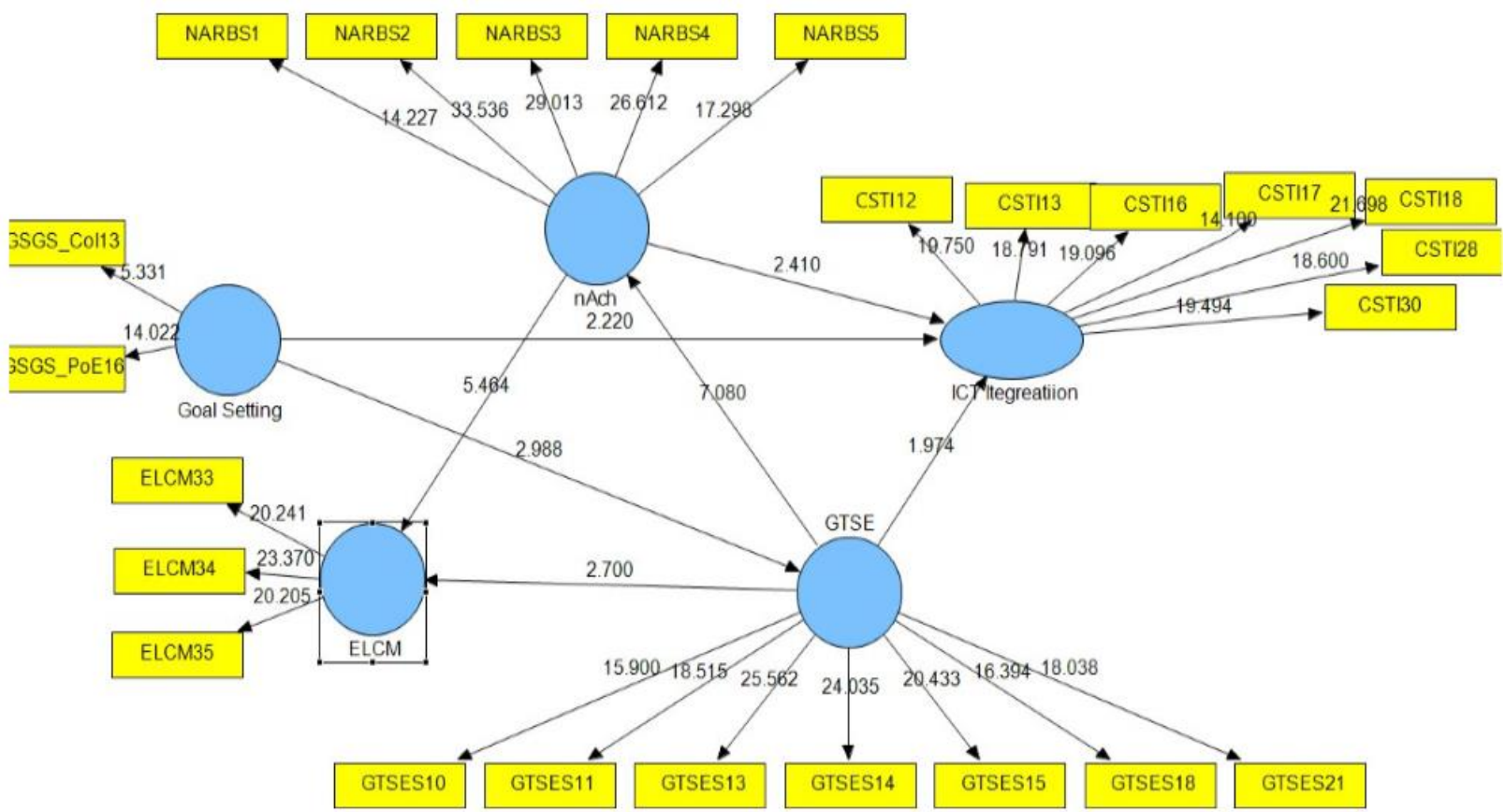

Figure-1. Bootstrapping for ICT Integration measurement and inner model.

\subsection{Discriminant and Convergent Statistics for the Measurement Model}

To ensure that measurement model would be suitable for the structural model, SEM researchers calls for further model testing that include the average variance extracted (AVE), composite reliability, and Cronbach's alpha values. Table 1 shows the cross-loadings of the 5-latent variables as convergent validity results. Convergent validity measures internal consistency (Cronbach Alpha) and the composite reliability based on Fornell and Larcker's criterion of 0.50 (AVE) (Henseler, Ringle, \& Sinkovics, 2009). Weak convergent was not an issue for the current study since ICT integration variable (0.576) and economic locus of control (0.65) all had AVE scores above the minimum. Except goal-setting construct (0.386), all the latent variables scored Cronbach alpha above 0.50; assuring the discriminant validity of the five constructs in this study.

Another model fit statistics produced in Table 1 is the discriminant validity of the latent variables in this study. Convergent validity uses the squared root of the AVE for respective latent constructs, which should be higher than their respective cross-loadings (Garson, 2016). The first part of the table passed the test that the square root of AVE extracted must be higher than the cross-loadings of the latent variables; meaning multicollinearity $(r$-values $>=.9)$ did not pose a challenge for the measurement

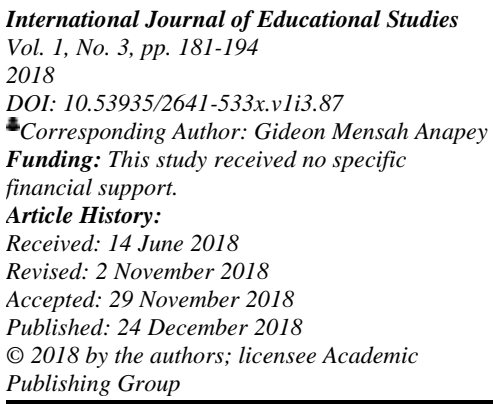




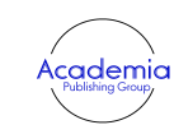

International Journal of Educational Studies Vol. 1, No. 3, pp. 181-194 2018

DOI: 10.53935/2641-533x.v1i3.87

- Corresponding Author: Gideon Mensah Anapey Funding: This study received no specific financial support.

Article History:

Received: 14 June 2018

Revised: 2 November 2018

Accepted: 29 November 2018

Published: 24 December 2018

(c) 2018 by the authors; licensee Academic

Publishing Group model. For instance, the need for achievement latent factor had a significant moderate positive relationship $(r=.484, \mathrm{p}<.05)$, less than the 0.806 AVE extracted.

\begin{tabular}{lllllllll}
\multicolumn{7}{l}{ Table-1. Discriminant and Convergent Statistics for Latent Variables in the Model. } \\
\hline LV & ELCM & GTSE & $\begin{array}{l}\text { Goal } \\
\text { Setting }\end{array}$ & ICT & nAch & AVE & $\begin{array}{l}\text { Composite } \\
\text { Reliability }\end{array}$ & $\begin{array}{l}\text { Cronbach's } \\
\text { Alpha }\end{array}$ \\
\hline ELCM & 0.806 & & & & & 0.650 & 0.848 & 0.730 \\
GTSE & 0.401 & 0.759 & & & & 0.576 & 0.905 & 0.877 \\
Goal Setting & 0.195 & 0.213 & 0.784 & & & 0.615 & 0.760 & 0.386 \\
ICT & 0.213 & 0.31 & 0.232 & 0.754 & & 0.568 & 0.902 & 0.874 \\
nAch & 0.484 & 0.483 & 0.175 & 0.313 & 0.797 & 0.635 & 0.896 & 0.855 \\
\hline
\end{tabular}

Note: Squared root of AVE (bolded) with cross-loadings

\section{Research Findings}

\subsection{Results of Hypothesis 1}

Students' cognitive traits will not significantly predict students' technology integration literacy in higher education,

The results of the structural model predicting students' technology integration literacy from four cognitive variables are presented in this section. Hypothesis 1 sought to explain what cognitive factors were more likely to influence Ghanaian graduates' technology integration literacy in higher education. The results in Figure 2 indicate null hypothesis 1 was rejected in favour of the alternate. Hence, we concluded that indeed, a statically significant association exists between students' technology integration literacy, self-efficacy, goal-setting and need for achievement in this study. Collectively, the three exogenous variables explained $15.5 \%\left(R^{2}=0.155\right)$.

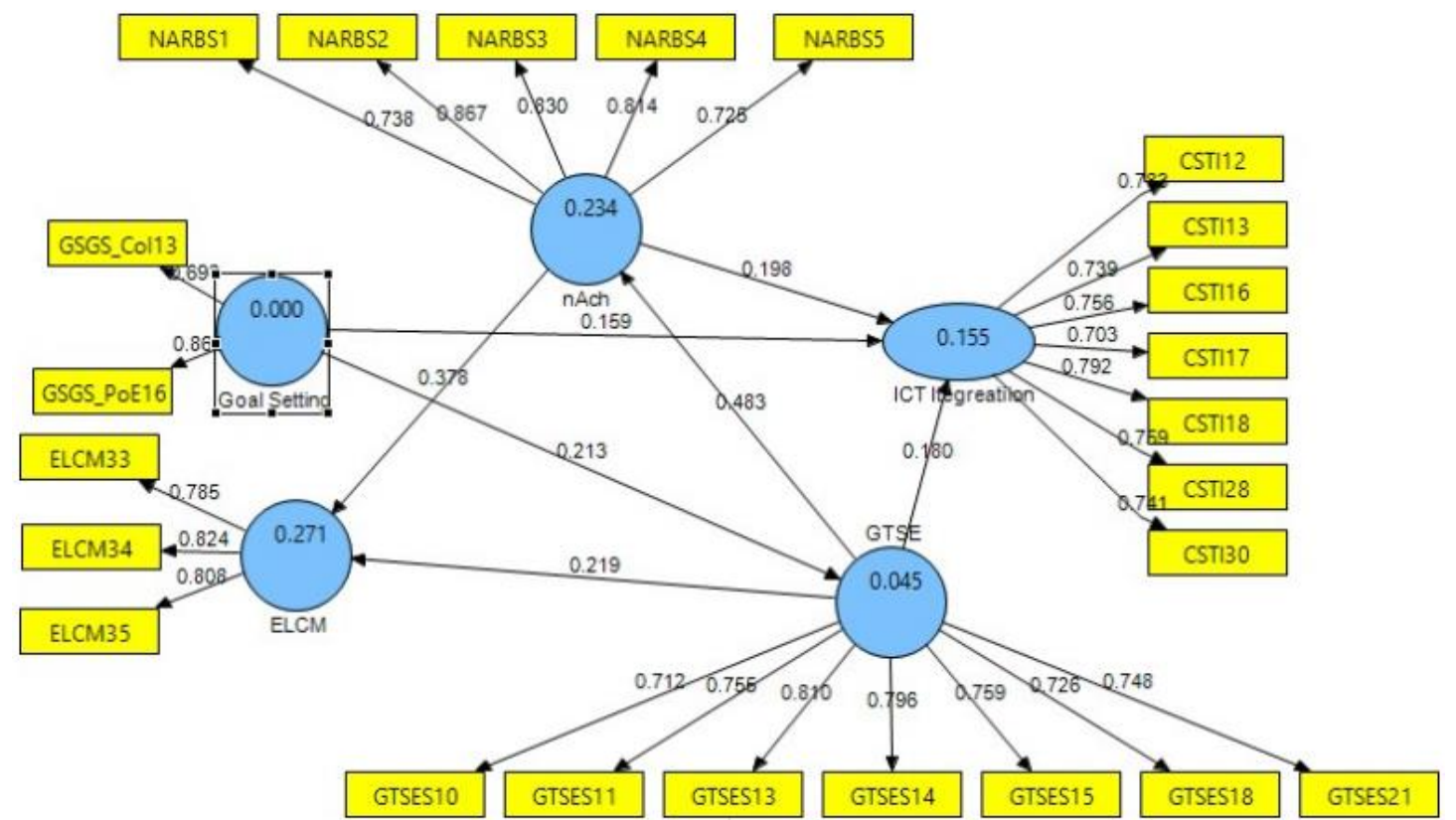

Figure-2. PLS Algorithm for the formative and structural models on students` ICT Integration Literacy.

\subsection{Results of Hypothesis 2}

Table 2 shows the t-test for path coefficients answering research hypotheses 2: there will not be statistical relationships between cognitive traits in this study. The results showed that self-efficacy had no statistical relationship $(t=1.74, p>.05)$ with ICT integration literacy. Specifically, we established that students' self-efficacy significantly predicated their economic locus of control $(t=2.60, p<.05)$, need for achievement $(t=6.72, p<.05)$, and goal-setting $(\mathrm{t}=3.26, p<.05)$. Also, students ${ }^{6}$ need for achievement behaviours were statistically associated with economic locus of control $(\mathrm{t}=4.81, p<.05)$ and technology integration in education $(\mathrm{t}=2.61, p<.05)$. 
Table-2. T-Statistics for Inner Model / Path Analysis

\begin{tabular}{lllllll}
\hline & $\begin{array}{l}\text { Original } \\
\text { Sample } \\
(\mathbf{O})\end{array}$ & $\begin{array}{l}\text { Sample } \\
\text { Mean } \\
(\mathbf{M})\end{array}$ & $\begin{array}{l}\text { Standard } \\
\text { Deviation } \\
\text { (STDEV) }\end{array}$ & $\begin{array}{l}\text { Standard } \\
\text { Error } \\
\text { (STERR) }\end{array}$ & $\begin{array}{l}\text { T } \\
\text { (|O/STERR|) }\end{array}$ & \\
& 0.219 & 0.207 & 0.084 & 0.084 & 2.601 & $s$ \\
GTSE -> ELCM & 0.180 & 0.179 & 0.104 & 0.104 & 1.736 & $n s$ \\
GTSE -> ICT & 0.483 & 0.493 & 0.072 & 0.072 & 6.724 & $s$ \\
GTSE -> nAch & 0.213 & 0.221 & 0.065 & 0.065 & 3.258 & $s$ \\
Goal Setting -> GTSE & 0.159 & 0.173 & 0.074 & 0.074 & 2.158 & $s$ \\
Goal Setting -> ICT & 0.378 & 0.385 & 0.079 & 0.079 & 4.810 & $s$ \\
nAch -> ELCM & 0.198 & 0.180 & 0.076 & 0.076 & 2.609 & $s$ \\
nAch -> ICT & & & & & & \\
\hline
\end{tabular}

Note: Significance at .05 alpha value, ns (not significant), s (significant)

\section{Conclusion, and Recommendations}

Perhaps, a practical significance of the current finding can be seen with the works of educational administration and management professionals in Ghanaian schools. Increasing disruption, high volatility, and growing diversity have dominated market indices in many sectors (formal and informal), including retailing, information technology, healthcare, education, pharmaceuticals, and host of others (Chiles et al., 2010). Therefore, with the realisation of the Ghana's ICT4AD policy, educational policy ought to account for nearly $85 \%$ (unexplained variance in this study) of factors can support students' technology integration literacy. For instance, faculty technology professional development initiatives, emphasis on technology integration literacy curriculum, and infrastructural development could be a priority for school managers. Our view is in tandem with Yidana (2007) position that Ghanaian teacher universities have to deal with low-technology environment if integration literacy should be attained.

Secondly, career-counsellors also have unique roles in developing students' cognitive traits and technology literacy, according to the current study. For instance, futuristic views of careerists postulate that in the world of high- tech, organisations today are experiencing tremendous change due to new technologies, rapid discoveries of knowledge, globalisation of businesses, and development of ecommerce as spurred by the Internet creating hyper- competition for firms on a global scale (Sullivan \& Baruch, 2009). Hence, school counsellors have significant roles to play in developing cognitive traits of their students since these traits are needed for successful transition into the world of work. Whilst we concluded that multiple cognitive variables could be required to use technology in higher education, our key recommendations for counselling interventions should combine multiple cognitive constructs in developing students' technology integration literacy. In addition, curriculum reforms should be considered to help teachers explore students " technology skills.

\section{References}

Ács, Z. J., Szerb, L., \& Autio, E. (2015). Global entrepreneurship index. Washington, DC: Global Entrepreneurship and Development Institute.

African Economic Outlook. (2015). Regional development and spatial inclusion. Retrieved from www.africaneconomicoutlook.org.

Arnett, J. J. (2000). Emerging adulthood: A theory of development from the late teens through the twenties. American Psychologist, 55(5), 469-480.Available at: https://doi.org/10.1037/0003-066x.55.5.469.

Aryeetey, E., \& Baah-Boateng, W. (2007). Growth, investment and employment. Ghana. NY: International Labour Organization (ILO).

Atkinson, J. W. (1958). Motives in fantasy, action and society: A method of assessment and study. Princeton, NJ: Van-Nostrand.

Austin, M. J., \& Nauta, M. M. (2016). Entrepreneurial role-model exposure, self-efficacy, and women's entrepreneurial intentions. Journal of Career Development, 43(3), 260-272.Available at: https://doi.org/10.1177/0894845315597475.

International Journal of Educational Studies Vol. 1, No. 3, pp. 181-194 2018

DOI: $10.53935 / 2641-533 x . v 1 i 3.87$

"Corresponding Author: Gideon Mensah Anapey Funding: This study received no specific financial support.

Article History:

Received: 14 June 2018

Revised: 2 November 2018

Accepted: 29 November 2018

Published: 24 December 2018

(c) 2018 by the authors; licensee Academic

Publishing Group

| 191
Ayres, H. W. (2005). Factors related to motivation to learn and motivation to transfer learning in a nursing population. North Carolina State University Unpublished Doctoral Dissertation: Raleigh.

Babbie, E. (2010). The practice of social research. Belmont, MA: Wadsworth, Cengage Learning.

Bandura, A. (1989). Regulation of cognitive processes through perceived self-efficacy. Developmental Psychology, 25(5), 729735.Available at: https://doi.org/10.1037/0012-1649.25.5.729.

Bandura, A. (2004). Swimming against the mainstream: The early years from chilly tributary to transformative mainstream. Behaviour Research and Therapy, 42(6), 613-630.Available at: https://doi.org/10.1016/j.brat.2004.02.001.

Bicego, M. L. (2006). Mentoring: Bridging the gap between learning and leadership development. Royal Roads University, Victoria. British Columbia, Canada: Royal Roads University, Victoria Unpublished Doctoral Dissertation. 
Britner, S. L., \& Pajares, F. (2006). Sources of science self-efficacy beliefs of middle school students. Journal of Research in Science Teaching: The Official Journal of the National Association for Research in Science Teaching, 43(5), 485-499.Available at: https://doi.org/10.1002/tea.20131.

Cabrera, E. F. (2009). Protean organizations: Reshaping work and careers to retain female talent. Career Development International, 14(2), 186-201.Available at: https://doi.org/10.1108/13620430910950773.

Cader, H. A. (2008). The evolution of the knowledge economy. JRAP, 38(2), 117-129.

Celik, E. (2015). Mediating and moderating role of academic self-efficacy in the relationship between student academic support and personal growth initiative. Australian Journal of Career Development, 24(2), 105-113.Available at: https://doi.org/10.1177/1038416215583563.

Chen, C. C., Greene, P. G., \& Crick, A. (1998). Does entrepreneurial self-efficacy distinguish entrepreneurs from managers? Journal of Business Venturing, 13(4), 295-316.Available at: https://doi.org/10.1016/s0883-9026(97)00029-3.

Chiles, T. H., Tuggle, C. S., McMullen, J. S., Bierman, L., \& Greening, D. W. (2010). Dynamic creation: Extending the radical Austrian approach to entrepreneurship. Organization Studies, 31(1), 7-46.Available at: https://doi.org/10.1177/0170840609346923.

Chin, W. W., \& Newsted, P. R. (1999). Structural equation modeling analysis with small samples using partial least squares. Statistical Strategies for Small Sample Research, 1(1), 307-341.

Collins, M. E., Mowbray, C. T., \& Bybee, D. (1999). Establishing individualized goals in a supported education intervention: Program influences on goal-setting and attainment. Research on Social Work Practice, 9(4), 483-507.Available at: https://doi.org/10.1177/104973159900900405.

Cool, K., Dierickx, I., \& Jemison, D. (1989). Business strategy, market structure and risk-return relationships: A structural approach. Strategic Management Journal, 10(6), 507-522.

Currie, G., Tempest, S., \& Starkey, K. (2006). New careers for old? Organizational and individual responses to changing boundaries. International Journal of Human Resource Management, 17(4), 755-774.Available at: https://doi.org/10.1080/09585190600581733.

Daly, A. J., Moolenaar, N. M., Bolivar, J. M., \& Burke, P. (2010). Relationships in reform: The role of teachers' social networks. Journal of Educational Administration, 48(3), 359-391.Available at: https://doi.org/10.1108/09578231011041062.

Diefendorff, J., Snyder, D., \& Lord, R. (1997). The effects of inhibitory processes on goal directed cognitions. St. Louis, MO: Annual Society for Industrial and Organizational Psychology.

Eby, L. T., Butts, M., \& Lockwood, A. (2003). Predictors of success in the era of the boundaryless career. Journal of Organizational Behavior: The International Journal of Industrial, Occupational and Organizational Psychology and Behavior, 24(6), 689708.Available at: https://doi.org/10.1002/job.214.

Elizur, D. (1986). Achievement motive and sport performance. International Review of Applied Psychology, 35(2), 209-224.Available at: https://doi.org/10.1111/j.1464-0597.1986.tb00917.x.

Elliot, A. J., \& Harackiewicz, J. M. (1994). Goal setting, achievement orientation, and intrinsic motivation: A mediational analysis. Journal of Personality and Social Psychology, 66(5), 968.Available at: https://doi.org/10.1037/0022-3514.66.5.968.

Field, A. (2009). Discovering statistics using SPSS. London: SAGE Publications Ltd.

Ford, M. (1992). Motivating humans: Goals, emotions, and personal agency beliefs. Newbury Park, CA: Sage.

Fournier, G., \& Jeanrie, C. (1999). Validation of a five-level locus of control scale. Journal of Career Assessment, 7(1), 6389.Available at: https://doi.org/10.1177/106907279900700105.

Francoise, U., \& Janviere, N. (2016). African S\&T professionals trained in Chinese universities orientations towards entrepreneurship. Science, Technology \& Society, 21(2), 296-314.Available at: https://doi.org/10.1177/0971721816640630.

Garson, D. G. (2016). Partial least squares: Regression \& structural equation mmodels. Asheboro, NC USA: Statisstical Publishing Associates.

Ghana's Education Reform Report. (2007). Meeting the challenges of education in the twenty-first century. Accra: Ministry Education. Ghana Publishing House.

Gómez-Miñambres, J. (2012). Motivation through goal setting. Journal of Economic Psychology, 33(6), 1223-1239.Available at: https://doi.org/10.1016/j.joep.2012.08.010.

Hair, J. F., Sarstedt, M., Ringle, C. M., \& Mena, J. A. (2012). An assessment of the use of partial least squares structural equation modeling in marketing research. Journal of the Academy of Marketing Science, 40(3), 414-433.

Hansemark, O., C. (1997). Objective versus projective measurement of need for achievement: The relation between TAT and CMPS. Journal of Managerial Psychology, 12(4), 280-289.Available at: https://doi.org/10.1108/02683949710174874.

Henseler, J., Ringle, C., \& Sinkovics, R. (2009). The use of partial least squares path modeling in international marketing. Advancesin International Marketing, 20(5), 277-319.

Hill, P. L., Jackson, J. J., Roberts, B. W., Lapsley, D. K., \& Brandenberger, J. W. (2011). Change you can believe in: Changes in goal setting during emerging and young adulthood predict later adult well-being. Social Psychological and Personality Science, 2(2), 123-131.Available at: https://doi.org/10.1177/1948550610384510.

International Journal of Educational Studies Vol. 1, No. 3, pp. 181-194 2018

DOI: 10.53935/2641-533x.v1i3.87

"Corresponding Author: Gideon Mensah Anapey Funding: This study received no specific financial support.

Article History:

Received: 14 June 2018

Revised: 2 November 2018

Accepted: 29 November 2018

Published: 24 December 2018

(C) 2018 by the authors; licensee Academic

Publishing Group

192
Hobbis, I. C., \& Sutton, S. (2005). Are techniques used in cognitive behaviour therapy applicable to behaviour change interventions based on the theory of planned behaviour? Journal of Health Psychology, 10(1), 7-18.Available at: https://doi.org/10.1177/1359105305048549.

Hoy, A. W., \& Spero, R. B. (2005). Changes in teacher efficacy during the early years of teaching: A comparison of four measures. Teaching and Teacher Education, 21(4), 343-356.Available at: https://doi.org/10.1016/j.tate.2005.01.007.

Inkson, K. (2007). Understanding careers: The metaphores of working lives. Thousand Oaks, CA: Sage Publications.

Johnson, B. R. (1990). Toward a multidimensional model of entrepreneurship: The case of achievement motivation and the entrepreneur. Entrepreneurship Theory and Practice, 14(3), 39-54.Available at: https://doi.org/10.1177/104225879001400306. 
Kelly, D. J., Ali, A., Brush, C., \& Corbett, A. C. (2012). Global entrepreneurship monitor (2012) (United States)— adult population survey. Retrieved from www.gemconsortium.

Kormanik, M. B., \& Rocco, T. S. (2009). Internal versus external control of reinforcement: A review of the locus of control construct. Human Resource Development Review, 8(4), 463-483.

Kruglanski, A. (1996). Goals as knowledge structures. In P. Gollwitzer, \& J. Bargh, The Psychology of Action: Linking Cognition and Motivation to Behavior. NY: The Guilford Press.

Lachman, M. E. (1986). Locus of control in aging research: A case for multidimensional and domain-specific assessment. Psychology and aging, 1(1), 34-40.Available at: https://doi.org/10.1037/0882-7974.1.1.34.

Laudon, K. C., \& Laudon, J. P. (2007). Management information systems: Managing the digital firm (10th ed.). Upper Saddle River, NJ: : Pearson Education Inc.

Lee, E. (2000). The future of work and changes in employment structure. Paper presented at the International Conference for Vocational Guidance Berlin, Germany.

Lefcourt, H. M. (1991). Locus of control. In J. P. Robinson, P. R. Shaver, \& L. S. Wrightsman, Measures of personality and social psychological attitudes. New York: Academic Press.

Lent, R. W., Brown, S. D., Gover, M. R., \& Nijjer, S. K. (1996). Cognitive assessment of the sources of mathematics self-efficacy: A thought-listing analysis. Journal of Career Assessment, 4(1), 33-46.Available at: https://doi.org/10.1177/106907279600400102.

Lent, R. W., Brown, S. D., \& Hackett, G. (1994). Toward a unifying social cognitive theory of career and academic interest, choice, and performance. Journal of Vocational Behavior, 45(1), 79-122.Available at: https://doi.org/10.1006/jvbe.1994.1027.

Lloyd, T., \& Hastings, R. P. (2009). Parental locus of control and psychological well-being in mothers of children with intellectual disability. Journal of Intellectual and Developmental Disability, 34(2), 104-115.Available at: https://doi.org/10.1080/13668250902862074.

Locke, E. A., \& Latham, G. P. (1990). A theory of goal setting and task performance. Englewood Cliffs, NJ: Prentice Hall.

Locke, E. A., Shaw, K. N., Saari, L. M., \& Latham, G. P. (1981). Goal setting and task performance: 1969-1980. Psychological Bulletin, 90(1), 125-152.Available at: https://doi.org/10.1037/0033-2909.90.1.125.

Lord, E. G. (2010). A quantitative study on executive coaching from a learning transfer perspective. AZ: University of Phoenix Unpublished Doctoral Dissertation.

Mackenzie, C. S., \& Peragine, G. (2003). Measuring and enhancing self-efficacy among professional caregivers with individuals with dementia. American Journal of Alzheimer's Disease and Other Dementias, 18(5), 291-299.Available at: https://doi.org/10.1177/153331750301800507.

Marsh, R. L., Hicks, J. L., \& Bink, M. L. (1998). Activation of completed, uncompleted, and partially completed intentions. Journal of Experimental Psychology: Learning, Memory, and Cognition, 24(2), 350-361.Available at: https://doi.org/10.1037/02787393.24.2.350.

Marsh, R. L., Hicks, J. L., \& Bryan, E. S. (1999). The activation of unrelated and canceled intentions. Memory \& Cognition, 27(2), 320-327.Available at: https://doi.org/10.3758/bf03211415.

Matthews, L. S., \& Dagher, G. K. (2007). Need for achievement, business goals, and entrepreneurial persistence. Management Research News, 30(12), 928-941.Available at: https://doi.org/10.1108/01409170710833358.

McClelland, D. C. (1961). The achievement society. Princeton, NJ: Van Nostrand.

McMillan, J. H. (2007). Classroom assessment: Principles and practice for effective standard-based instruction. Boston, MA: Pearson Education Inc.

Meacham, K. A. (2004). The role of attention in goal setting theory. Unpublished Master of Science in Psychology Thesis. Virginia Polytechnic Institute and State University, Blacksburg, Virginia.

Millar, R., \& Shevlin, M. (2007). The development and factor structure of a career locus of control scale for use with school pupils. Journal of Career Development, 33(3), 224-249.Available at: https://doi.org/10.1177/0894845306296643.

Munive, J. (2008). The army of unemployed'young people. Young, 18(3), 321-338.

National Council for Tertiary Education. (2016). Public university regular enrollment and field of study (2016-2017)- Unpublised work of the NCTE. Ghana, Accra: NCTE.

National ICT for Accelerated Development Policy. (2003). Government of Ghana's framework for ICT deployment.

Pajares, F., Johnson, M. J., \& Usher, E. L. (2007). Sources of writing self-efficacy beliefs of elementary, middle, and high school students. Research in the Teaching of English, 42(1), 104-120.

Perry, J. C., Liu, X., \& Griffin, G. C. (2011). The career locus of control scale for adolescents: Further evidence of validity in the United States. Journal of Career Development, 38(2), 167-185.Available at: https://doi.org/10.1177/0894845310372616.

Phillips, J. J., \& Whalen, P. J. (2000). Return on investment for technology-based training: Building the business case. In G. M. Piskurich, P. Beckschi, \& B. Hall, The ASTD handbook of training design and delivery: A comprehensive guide to creating and delivering training programs - instructor-Led, computer-based. or self-directed (pp. 216-236). NY: McGraw-Hill.

International Journal of Educational Studies Vol. 1, No. 3, pp. 181-194

Pintrich, P. R. (2000). An achievement goal theory perspective on issues in motivation terminology, theory, and research Contemporary Educational Psychology, 25(1), 92-104.Available at: https://doi.org/10.1006/ceps.1999.1017.

Popham, W. J. (2005). Classroom assessment: What teachers need to know. Boston, MA: Allyn \& Bacon.

Pratt, P. J., \& Adamski, J. J. (2005). Concepts of database management (5th ed.). Boston, MA: Thomson Course Technology.

Reich, R. (1996). The work of nations. Lisboa: Quetzal.

Reinartz, W., Haenlein, M., \& Henseler, J. (2009). An empirical comparison of the efficacy of covariance-based and variance-based SEM. International Journal of Research in Marketing, 26(4), 332-344.Available at: https://doi.org/10.1016/j.ijresmar.2009.08.001.

Reisberg, D. (2010). Cognition: Exploring the science of the mind (4th ed.). NY: W. W. Noron \& Company, Inc. 
Ringle, C. M., Silva, D., \& Bido, D. (2014). Structural equation modeling with the smartpls. Brazilian Journal of Marketing, 13(2), 173.

Rollinson, D., Broadfield, A., \& Edwards, D. J. (1998). Organisational behaviour and analysis: An integrated approach. Harlow: Addison-Wesley.

Rotter, J. (1966). Generalised expectancies for internal versus external control of reinforcement. Psychological Monographs: General and Applied, 80(1), 1-28.Available at: https://doi.org/10.1037/h0092976.

Ryan, R. M., \& Connell, J. P. (1989). Perceived locus of causality and internalization: Examining reasons for acting in two domains. Journal of Personality and Social Psychology, 57(5), 749-761.Available at: https://doi.org/10.1037/0022-3514.57.5.749.

Sagie, A. (2002). Taking another look at the need for achievement: Expanding the construct meaning and testing its structural equivalence. Vision, 6(1), 1-12.Available at: https://doi.org/10.1177/097226290200600101.

Sánchez, J. C., Carballo, T., \& Gutiérrez, A. (2011). The entrepreneur from a cognitive approach. Psicothema, 23(3), $433-438$.

Sargent, L. D., \& Domberger, S. R. (2007). Exploring the development of a protean career orientation: Values and image violations. Career Development International, 12(6), 545-564.Available at: https://doi.org/10.1108/13620430710822010.

Scott, J. (2006). Social theory: Central issues in sociology. London: Sage Publications Ltd.

Senler, B. (2016). Pre-service science teachers' self-efficacy: The role of attitude, anxiety and locus of control. Australian Journal of Education, 60(1), 26-41.Available at: https://doi.org/10.1177/0004944116629807.

Shaffer, D. R., \& Kipp, K. (2007). Developmental psychology (7th ed.). Belmount, CA: Thomson Wadsworth.

Shelly, G. B., Cashman, T. J., Gunter, G. A., \& Gunter, R. E. (2006). Teachers discovering computers: Integrating technology and digital media in the classroom (4th ed.). Boston, Massachusetts: Thomson Course Technology.

Simons, D. J., \& Chabris, C. F. (1999). Gorillas in our midst: Sustained inattentional blindness for dynamic events. Perception, 28(9), 1059-1074.Available at: https://doi.org/10.1068/p281059.

Smith, K. G., \& Hitt, M. A. (2005). Great minds in management: The process of theory development. Oxford, NY: Oxford University Press.

Spector, P. E. (1982). Behavior in organizations as a function of employee's locus of control. Psychological Bulletin, 91(3), 482497.Available at: https://doi.org/10.1037/0033-2909.91.3.482.

Sullivan, S. E., \& Baruch, Y. (2009). Advances in career theory and research: A critical review and agenda for future exploration. Journal of Management, 35(6), 1542-1571.Available at: https://doi.org/10.1177/0149206309350082.

Super, D. E., Savickas, M. L., \& Super, C. M. (1996). The life-span, life-space approach to careers. In D. Brown, \& L. Brooks, Career choice and development: Applying contemporary theories to practice (pp. 121-178). San Francisco, CA: Jossey-Bass.

The Republic of Ghana. (2003). The Ghana ICT for accelerated development (ICT4AD) policy. Accra: Ghana Publishing House.

Usher, E. L. (2009). Sources of middle school students' self-efficacy in mathematics: A qualitative investigation. American Educational Research Journal, 46(1), 275-314.Available at: https://doi.org/10.3102/0002831208324517.

Vancouver, J. B., More, K. M., \& Yoder, R. J. (2008). Self-efficacy and resource allocation: Support for a nonmonotonic, discontinuous model. Journal of Applied Psychology, 93(1), 35-47.Available at: https://doi.org/10.1037/0021-9010.93.1.35.

Vardi, Y., \& Kim, S. H. (2007). Considering the darker side of careers: Toward a more balanced perspective. In H. P. Gunz, \& M. A. Peiperl, Handbook of career studies (pp. 502-510). Thousand Oaks, CA: Sage.

Venkatapathy, R. (1984). Locus of control among entrepreneurs: A review. Psychological Studies, 29(1), 97-100.

Wise, J. B. (2007). Testing a theory that explains how self-efficacy beliefs are formed: Predicting self-efficacy appraisals across recreation activities. Journal of Social and Clinical Psychology, 26(7), 841-848.Available at: https://doi.org/10.1521/jscp.2007.26.7.841.

World Bank. (2013). The economist education in South Africa: Still dysfunctional. NY: World Bank.

Wright, P. M. (1992). A theoretical examination of the construct validity of operationalizations of goal difficulty. Human Resource Management Review, 2(4), 275-298.Available at: https://doi.org/10.1016/1053-4822(92)90002-8.

Yidana, I. (2007). Faculty perceptions of technology integration in the teacher education curriculum: A survey of two Ghanaian universities. Athens: Ohio University.

International Journal of Educational Studies Vol. 1, No. 3, pp. 181-194

2018

DOI: 10.53935/2641-533x.v1i3.87

"Corresponding Author: Gideon Mensah Anapey Funding: This study received no specific

financial support.

Article History:

Received: 14 June 2018

Revised: 2 November 2018

Accepted: 29 November 2018

Published: 24 December 2018

(C) 2018 by the authors; licensee Academic

Publishing Group

194 